\title{
Endringer i forståelsen av dannelse i skolens religions- og livssynsfag Om noen utfordringer til faget $i$ juridiske og pedagogiske/didaktiske tekster og hvordan skriving kan vare med på å løse dem
}

\author{
Av Camilla Stabel Jørgensen
}

The article discusses changes in the interpretation of Bildung (dannelse) as it is conveyed in two pedagogical/ didactical articles and through legal documents (purpose clause, curriculum) current since 1997, when the $K R L$-subject was first introduced in Norwegian schools. In addition to the investigation of the concept of Bildung, the terms «religionspedagogikk» and «religions- og livssynsdidaktikk» (RE pedagogy and RE didactics) are discussed (note however that the translations of these terms do not convey the associations that are evoked by the Norwegian terms). The two terms, RE pedagogy and RE didactics can be related to theological and pedagogical foundation, historical time and the theory-practice dimension, and along these lines differences in the interpretation of Bildung can be traced. From the analysis of the legal documents and the articles, two different challenges for the RE/RLE-subject emerge - challenges that can be answered through writing. In its final part the article points out how and why writing can be seen as an appropriate way to both discover one's own thoughts and identity and to explore the views of others'.

Keywords: Bildung (dannelse), religious education, pedagogy, didactics, writing

\section{Camilla Stabel Jørgensen (f. 1974). Ph.D, 1. amanuensis ved Høgskolen i Sør-Trøndelag, Avdeling for lærer- og tolkeutdanning, 7004 Trondheim. Epost: Camilla.jorgensen@hist.no}

Hvordan har forståelser av dannelsesbegrepet endret seg gjennom religions- og livssynsfagets nyere historie? Begrepet «dannelse» er benyttet både $\mathrm{i}$ juridiske dokumenter som formålsparagraf og læreplan - og i religionspedagogisk og religionsdidaktisk litteratur knyttet til faget ${ }^{1}$. I disse skriftlige kildene er begrepet lett tilgjengelig for undersøkelse, mens det å undersøke hvordan ulike forståelser av «dannelse» har nedfelt seg i læreres praksis og elevers erfaringer med undervisning i religions- og livssynsfaget, er langt mer utfordrende. At det er utfordrende, betyr selvfølgelig ikke at man skal avstå fra å forsøke (Haslund 2014; Jørgensen 2014), men innenfor rammene av denne artikkelen skal jeg avgrense meg til å undersøke begrepet i to artikler og i noen av de juridiske dokumentene. Undersøkelsen synliggjør to utfordringer for religions- og livssynsfaget. Avslutningsvis reflekterer jeg over hvordan den grunnleggende ferdigheten skriving kan brukes for å løse disse utfordringene.

De to artiklene jeg har valgt ut er «Fragmentert

1 Artikkelen er bearbeidet til artikkel for Prismet med utgangspunkt i forfatterens prøveforelesning holdt ved NTNU 17. januar 2014. 
dannelse eller dannelse av fragmenter? Om dannelse, religion, «vår tid» og vårt sted» av Geir Afdal (2001) og «Religionskritikk som dannelse $\gg$ av Bengt-Ove Andreassen (2010). Disse artiklene er valgt fordi jeg mener de kan illustrere endringer i dannelsesbegrepet i fagets nyere historie, og en spenning mellom to til dels ulike tilnærminger til faget: religionspedagogikk og religions- og livssynsdidaktikk. Med begrepsparet religionspedagogikk og religionsog livssynsdidaktikk sikter jeg til henholdsvis teologisk skolert, men pedagogisk fundert religionspedagogikk og religionsvitenskapelig skolert, pedagogisk fundert religions- og livssynsdidaktikk. De juridiske dokumentene jeg vil undersøke, er de to formålsparagrafene (fra 1998 og 2009), generell del til læreplanen (gjeldende fra 1993) og Læringsplakaten (innført 2006), samt formål for KRL-faget fra 1997, 2002, 2005 og for RLE-faget fra 2008 (Bostadutvalget
2006; «Formålsparagrafen i opplæringslova» 2008).

Med formuleringen «religions- og livssynsfagets nyere historie» sikter jeg til grunnskolefagets historie fra innføringen av det felles, ikke-konfesjonelle KRL-faget i 1997 til etter den (foreløpig) siste læreplanrevisjonen av faget, da det også fikk nytt navn: $\mathrm{RLE}^{2}$. Det er altså grunnskolens religions- og livssynsfag som står i fokus.

Dannelsesbegrepet har fått så stor oppmerksomhet fra så mange over så lang tid, at det er vanskelig å definere presist. En grunn er at selv om det har vært knyttet til oppdragelse og utdanning, har målene og de foretrukne midlene knyttet til oppdragelse og utdanning, skiftet opp gjennom historien, og variert mellom ulike deltagere i dialogen om dannelse. Ved å benytte en rekke akser (se nedenfor) håper jeg å kunne synliggjøre endringer, spenninger og nyanser

\begin{tabular}{|l|l|}
\hline Hvem bør dannes? & Alle - noen utvalgte \\
\hline Hvordan kan/bør dannelse fremmes? & Ytre påvirkning - indre utvikling \\
\hline $\begin{array}{l}\text { Er dannelse noe alle har/får, eller noe man må strebe } \\
\text { for å oppnå }\end{array}$ & Oppnåelig - uunngåelig \\
\hline $\begin{array}{l}\text { Hva slags kunnskap bør stå i fokus for en dannelses- } \\
\text { prosess? }\end{array}$ & Nyttig kunnskap - klassisk kunnskap \\
\hline Hva er målet for en dannelsesprosess? & Styrke tro (frelse) - utfordre tro \\
\hline Hva bør vektlegges i en dannelsesprosess? & Resultat - prosess \\
\hline $\begin{array}{l}\text { Hva kjennetegner mennesker som har gjennomgått } \\
\text { en dannelsesprosess? }\end{array}$ & Selvstendighet - lydighet \\
\hline $\begin{array}{l}\text { Hva slags innstilling har de til samfunnet/samfunnets } \\
\text { aktuelle orden? }\end{array}$ & Bevare - endringsvilje \\
\hline $\begin{array}{l}\text { Hva bør vektlegges som grunnlag for å bevare/endre } \\
\text { samfunnet? }\end{array}$ & $\begin{array}{l}\text { Fremme herskende verdi - innlevelse (i marginali- } \\
\text { serte gruppers situasjon) }\end{array}$ \\
\hline
\end{tabular}

Figur 1: Spørsmål og akser med relevans for å karakterisere forståelser av dannelse som kommer til uttrykk i tekster

2 Da faget ble innført i 1997, sto forkortelsen KRL for Kristendomskunnskap med religions- og livssynsorientering. Etter en evaluering av faget (Aadnanes 2000) ble fagplanen revidert i 2002, og navnet endret til Kristendoms-, religions- og livssynskunnskap. I forbindelse med innføringen av Kunnskapsløftet 2006, men fremskyndet av uttalelsene i FNs menneskerettighetskomité i 2004, fikk faget ny læreplan i 2005. Etter dommen i Den Europeiske Menneskerettighetsdomstolen i 2007 ble fagplanen revidert og nytt navn innført fra høsten 2008. 
i dannelsesbegrepet slik det benyttes i de to artiklene og i de juridiske dokumentene. Aksene i høyre kolonne illustrerer spenn der ulike aktører til ulike tider har plassert seg gjennom sine (eksplisitte eller implisitte) svar på spørsmålene i venstre kolonne (se Figur 1, s. 66).

Ofte vil bidragsytere til (den historiske) dialogen om dannelse posisjonere seg i den ene enden av en akse, men ikke nødvendigvis: ikke alle tematiserer alle forhold, noen posisjonerer seg eksplisitt mellom ytterpunkter, eller insisterer på at dannelsesbegrepet må omfatte begge ytterpunktene på en akse - for eksempel omfatte både klassisk og nyttig kunnskap.

Med et kort riss i deler av den historiske dialogen om dannelse vil jeg nedenfor illustrere hvordan aksene kan bidra til å synliggjøre endringer i dannelsesbegrepet:

Mange fører dannelsesbegrepet tilbake til paideia i den klassiske greske kulturen. Her var imidlertid tilgangen til dannelse avgrenset til noen få utvalgte: frie menn. Da allmueskolen ble innført i Norge i 1739, var den nettopp en allmueskole, for begge kjønn, åpen for alle. (Andersen 1999; Aristoteles 1999; Bø 2006; Doseth 2011; Haraldsø 1989; Holter 1989; Wyller 1999).

At den pietistiske kong Christian den 6. fikk innført allmueskolen, hang sammen med en overbevisning om at barn trengte ytre påvirkning dersom de skulle kunne oppnå den ønskede dannelse. Den kunnskapen de hadde bruk for, og som skolen derfor skulle gi opplæring i, var lesing. Lesing var nyttig fordi det satte barna i stand til å lese Bibelen. Bibelkunnskap var nødvendig for å kunne svare under konfirmasjonshøringen, som også fungerte som skolens eksamen. I og med konfirmasjonen som målet for skolens opplæring, var også frelse målet for skolens dannelse av elevene.

Frelse som mål for skolens undervisning, indikerer også en orientering mot resultatet av dannelsesprosessen. Og mens allmueskolens dannelse til frelse også innebar et ideal om lydige borgere, knyttes dannelsesbegrepet siden opplysningstiden og Kant (Kant 1784) ofte til selvstendig kritisk tenkning, og mot og vilje til a forandre det bestående samfunn. Det motet Kant mente var nødvendig for selvstendig, kritisk tenkning, mente Schiller (Schiller 1991) kunne mobiliseres gjennom følelsesmessig engasjement og innlevelse i andres situasjon. I norske læreplaner for religionsfaget dukker ikke interessen for andre religioner (og annerledes troende) opp før i planene for den høgre almenskolen fra 1950, og da for å gi bedre grunnlag for misjon. Med reformpedagogiske idealer - som kommer til uttrykk i grunnskolens planer fra og med 1939 formuleres imidlertid mål knyttet til toleranse og respekt, som kan sies å være knyttet til innlevelse (Kjelen 2005).

ENDRINGER I DANNELSESBEGREPET SLIK DET KOMMER TIL UTTRYKK I DE JURIDISKE DOKUMENTENE

I og med at mitt fokus er på endringer i dannelsesbegrepet, presenterer jeg ikke fyllestgjørende analyser av de juridiske dokumentene som tematiseres. Målet er å skissere endringer i det anvendte dannelsesbegrepet slik det kommer til uttrykk i det juridiske rammeverket faget er praktisert innenfor siden 1997, slik at tendensene som viser seg, kan danne bakgrunn for analysen av de to artiklene av henholdsvis Afdal (2001) og Andreassen (2010).

\section{Formålsparagrafene}

Da Norge ble dømt i Den Europeiske Menneskerettighetsdomstolen fordi KRLfagets kvantitative vektlegging av kristendom i kombinasjon med kristen formålsparagraf og begrenset fritaksrett ble ansett å være brudd på «Article 2 of Protocol no. 1 of the Convention for the Protection of Human Rights and 
Fundamental Freedoms» (Lied 2009), var arbeidet med en ny formålsparagraf allerede i gang. Bostadutvalget - som i 2007 presenterte forslag til ny formålsparagraf - skulle i henhold til sitt mandat bl.a. vurdere «perspektiver som kommer fram i nyere offentlige utredninger, uttalelse fra FNs menneskerettskomité og oppfølgingen av disse i stortingsdokumenter» med tanke på «formuleringene om det kristne verdigrunnlaget i formålene». (Bostadutvalget 2007).

Formålsparagrafen har, fra den første gang ble innført i 1848, vist til kristendom i tilknytning til den opplæringen skolen skal gi, samtidig som «Kundskaber og Færdigheder» med relevans for samfunnet presenteres som mål. Den siste vedtatte formålsparagrafen før Bostadutvalgets utredning var fra 1998. Der er formuleringen av det kristne formålet formulert som en karakteristikk av oppdragelsens karakter: «Grunnskolen skal i samarbeid og forståing med heimen hjelpe til med å gi elevane ei kristen og moralsk oppseding» (Bostadutvalget 2006). I tillegg sier formålsparagrafen at grunnskolen skal «utvikle evnene og føresetnadene deira, åndeleg og kroppsleg, og gi dei god allmennkunnskap, slik at dei kan bli gagnlege og sjølvstendige menneske i heim og samfunn.» Denne formålsparagrafen inneholder ikke begrepet dannelse (danning), men formuleringen «gagnlege og sjølvstendige menneske i heim og samfunn» indikerer en interesse for målet for dannelsen. Gagnlege og sjølvstendige menneske kan tolkes som henvisning til et spenn som ligner det mellom selvstendighet og lydighet. Gagnleg viser riktignok til hvilken nytte mennesket kan gjøre for samfunnet ${ }^{3}$ - i motsetning til både lydighet og selvstendighet, som snarere karakteriserer måter mennesker forholder seg til samfunnet på.
I den formålsparagrafen som ble innført 1 . januar 2009 står det at

Opplaringa skal byggje på grunnleggjande verdiar $i$ kristen og humanistisk arv og tradisjon, slik som respekt for menneskeverdet og naturen, på åndsfridom, nestekjcerleik, tilgjeving, likeverd og solidaritet, verdiar som ò kjem til uttrykk $i$ ulike religionar og livssyn og som er forankra $i$ menneskerettane. («Formålsparagrafen i opplæringslova» 2008)

Her er det altså grunnlaget for opplæringen som knyttes til «kristen og humanistisk arv og tradisjon» - ikke prosessen. De verdiene som nevnes eksplisitt, knyttes samtidig til «ulike religionar og livssyn» og «menneskerettane». Selve utvalget av verdier er bare delvis nytt: paragrafen fra 1998 peker på «menneskeleg likeverd og likestilling, åndsfridom og toleranse, økologisk forståing og internasjonalt medansvar» som verdier opplæringen skal fremme. De som er «nye» i 2009, er altså nestekjærlighet, tilgivelse og solidaritet.

I den nye formålsparagrafen benyttes dannelsesbegrepet i nest siste setning: «Skolen og lærebedrifta skal møte elevane og lærlingane med tillit, respekt og krav og gi dei utfordringar som fremjar danning og lærelyst.» At skolen skal gi elevene utfordringer som fremmer dannelse, indikerer at dannelse forstås som noe man ikke nødvendigvis oppnår, og noe skolen ikke med sikkerhet, gjennom ytre påvirkning, kan sikre seg at elevene oppnår.

Målet for dannelsen, slik det kommer til uttrykk i den nye formålsparagrafen, er at elevene skal «meistre liva sine», «delta i arbeid og fellesskap i samfunnet», «utfalde skaparglede, engasjement og utforskartrong» og «tenkje kritisk og handle etisk og miljøbevisst». Dette

3 I formålsparagrafen fra 1936 er også nyttebegrepet benyttet: «Folkeskolen skal hjelpe til å gi barna en kristelig og moralsk oppdragelse og arbeide for å gjøre dem til nyttige mennesker både åndelig og legemlig.» (Bostadutvalget 2006) 
med å mestre livene sine og delta i arbeid og fellesskap, er, slik jeg ser det, uttrykk for noe av det som ligger $\mathrm{i}$ formuleringen om gagnlege menneske: de som mestrer livene sine, arbeider og deltar, bidrar til samfunnet. Kan den nye formålsparagrafens formuleringer om å utfolde skaperglede, engasjement og utforskertrang, å tenke kritisk og å handle etisk og miljøbevisst sees som en konkretisering og utvidelse av målet om selvstendighet? Utforskertrang og å tenke kritisk lar seg lett knytte til idealet om selvstendighet. Men kan det å utfolde skaperglede, engasjement og å handle etisk og miljøbevisst sees som en utvidelse av målet om selvstendighet fra å ha et kognitivt innhold (tenke kritisk og selvstendig) til også å omfatte følelser og handlinger (skaperglede, engasjement og etisk og miljøbevisst handling)?

Når det gjelder målet om at elevene skal handle etisk og miljøbevisst, kan det både betraktes som uttrykk for styrking av anerkjente verdier, og ønske om å bevare (natur og klima). Men - som Bostadutvalget selv er inne på (NOU 2007:6) er det i tilknytning til etikk og miljøbevissthet et sprik mellom samfunnsmessig anerkjente verdier og alminnelig praksis. Med hensyn til bevaringsog endringsvilje omfatter derfor - slik jeg oppfatter det, den nye formålsparagrafens dannelsesbegrep hele spennet: Man vil bevare en utbredt og anerkjent miljøbevissthet, men endre samfunnet i den grad handlinger ikke er etiske og miljøbevisste.

Jeg finner altså to vesentlige endringer i dannelsesbegrepet slik det kommer til uttrykk gjennom formålsparagrafene fra henholdsvis 1998 og 2009. For det første at den forrige karakteriserte dannelsesprosessen som «kristen og moralsk», mens den nye forankrer konkrete verdier som dannelsen skal fremme både i humanistisk og kristen tradisjon, i andre religiøse tradisjoner og i menneskerettighetene. For det andre at den nye har tydeligere ambisjoner ikke bare for elevenes tenkning, men også deres følelser og handlinger.

\section{Generell del av læreplanen og Prinsipp for opplæringa}

Generell del av læreplanen ble innført for grunnskolen med L97, og beholdt i Kunnskapsløftet. Telhaug (2011) kritiserer dannelsestenkningen i Generell del som material ${ }^{4}$ :

At så var tilfellet, ser vi også av hans [Hernes'] hyppige bruk av ord og vendinger som «tradisjon», «kultur», «arv», «de kristne og humanistiske verdiene» og «de grunnleggende referanserammene $i$ de forskjellige fagene». Vi ser det også av den vekten som han la på nyttig kunnskap og nyttige ferdigheter, som for eksempel teknologisk viten og ferdigheter (Telhaug 2011: 246).

Jeg er enig med Telhaug $\mathrm{i}$ at Generell del understreker nødvendigheten av kunnskap. Og at den kunnskapen som verdsettes, spenner fra det jeg betegner som nyttig kunnskap til klassisk kunnskap. Men jeg finner også interesse for holdninger i Generell del:

Oppfostringen skal fremme likestilling mellom kjønn og solidaritet på tvers av grupper og grenser. (...) Oppfostringen skal motvirke fordommer og diskriminering og fremme gjensidig respekt og toleranse mellom grupper med ulike levesett. (...) Åndsfrihet innebcerer ikke bare romslighet for andre syn, men også mot til å ta personlig standpunkt, trygghet til å stå alene og karakterstyrke til å tenke og handle etter egen

\footnotetext{
4 Danningsteorier med fokus på det stoffet den enkelte må møte, betegnes ofte som materiale. Andre har i større grad fokusert på prosessen og argumentert for at det vesentlige ikke er hva den enkelte møter, men at man møter det og de man møter, med dannelse. Klafki betegner teoriene med fokus på prosessen som formale danningsteorier (Klafki 2001, 2011). Telhaug bruker begrepene i tråd med Klafki.
} 
overbevisning. (Kirke-, utdannings- og forskningsdepartementet 1996. Generell del: Det meningssøkende mennesket: 4-5)

Og jeg vurderer det slik at denne interessen for holdninger peker ut over material dannelsestenkning, for holdninger har med handlinger å gjøre: de angår hvilke handlinger man er disponert for. Og hvordan man handler, viser seg bl.a.i hvordan man møter kunnskapsstoff. Formal dannelsestenkning er da heller ikke fraværende i Generell del, selv om teksten ikke domineres av det:

Barns nyfikenhet er et forbilde for alle som skal utvikle seg og lare ... (...). Både ved eksempler og praksis bor opplaringen gi erfaringer med disse trinnene i forskning - som nettopp svarer til barns og unges naturlige vitebegjcer: å gjøre iakttagelser, å søke og finne forklaringer, å se implikasjoner og prøve holdbarhet. (Kirke-, utdannings- og forskningsdepartementet 1996. Generell del: Det skapende menneske: 6-8)

Prinsipp for opplæringa ble innført i 2006. Den sier at skolen skal «stimulere elevane (...) til å utvikle eigne læringsstrategiar og evne til kritisk tenking», og «stimulere elevane (...) i personleg utvikling og i styrking av eigen identitet, i det å utvikle etisk, sosial og kulturell kompetanse og evne til demokratiforståing og demokratisk deltaking », samt legge til rette for demokratiopplæring gjennom medvirkning og egne valg. Bl.a. skal

Elevane (...) kunne delta i planlegging, gjennomføring og vurdering av opplaringa innanfor ramma av lov og forskrift, medrekna lcereplanverket. Kor omfattande medverknaden er, og korleis elevane medverkar, vil variere blant anna med alder og utviklingsnivå. (Prinsipp for opplæringa 2006)
I tillegg til interessen for kritisk tenkning, som også formuleres eksplisitt her, pekes det på læringsstrategier og medvirkning - forhold som angår handling. I sin drøfting av Kunnskapsløftet fremhever Telhaug nytte, frihet, valgfrihet, mangfoldighet og individualisme (Telhaug 2011: 246ff): «Med den nye læreplanen skal altså oppmerksomheten først og fremst rettes mot elevenes handlingskompetanse, mot hva de kan gjøre, mer enn mot hva de kan dokumentere at de vet.» (Telhaug 2011: 248) Selv om reformens navn indikerer en interesse for kunnskap - uspesifisert i forhold til nytte og klassisk karakter, peker altså Prinsipp for opplæringa snarere på formale forhold, altså forhold knyttet til prosessen, snarere enn innhold. Og målet for den dannelsesprosessen som angis, er også knyttet til hvordan elevene skal kunne forholde seg til nye utfordringer nemlig kompetent.

Både Generell del og Prinsipp for opplæringa er tydelige i sine oppfordringer om å legge til rette for at elevene skal øve seg i å tenke kritisk. Mens Generell del peker ut både klassisk kunnskap og nyttig kunnskap og bestemte holdninger som mål for elevenes dannelsesprosess, er målene for dannelsesprosessen som formuleres i Prinsipp for opplæringa primært konsentrert om kompetanser elevene skal tilegne seg gjennom deltagelse i bestemte prosesser som del av opplæringen: målet er altså å skape gode prosesser.

\section{Innledning til fagplan og formåls - beskrivelser for faget}

I L97 innledes fagplanen for KRL med avsnitt om «Fagets plass i skolen», «Kort historikk», «Arbeidsmåter i faget» og «Strukturen i faget». Også den reviderte fagplanen fra 2002 har en slik innledning, mens fagplanene fra 2005 og 2008 har innledende avsnitt betegnet som «Formål med faget $\gg$. Når det gjelder dannelsen som beskrives som mål for faget i disse dokumentene, endres 
beskrivelsene av den: i L97 og 2002-planen ansees faget å ha «flere funksjoner i grunnskolen: å formidle tradisjon, å ivareta identitet og å bygge broer som gir innsikt og fremmer samtale.» (Kirke-, utdannings- og forskningsdepartementet 1996; Læringssenteret 2002). Samtidig sies det i L97 at «Faget skal gi kunnskap om, ikke opplæring til, en bestemt tro. Det skal ivareta den enkelte elevs identitet ut fra egen tilhørighet, samtidig som det skal fremme dialog i en felles kultur.» I 2002-planen finnes en lignende formulering: «Faget skal gi kunnskap og forståelse, ikke opplæring til en bestemt religion eller et bestemt livssyn og ivareta den enkelte elevs identitet ut fra elevens egen tilhørighet og tradisjon.»

Begge disse innledningene formulerer det å ivareta identitet som et mål. Det forstår jeg som at elevene skal styrkes i sin tro - ikke én bestemt, men den som den enkelte elev er knyttet til. Samtidig peker de på nytten av kjennskap også til andre tradisjoner enn sin egen, for å fremme dialog og bygge en felles kultur.

Formål for faget fra 2005 inneholder ikke formuleringene om å styrke den enkelte elevs identitet, men faget skal bidra til "personlig utvikling", "bevissthet om egen identitet" og "gi gjenkjennelse ut fra elevens egen bakgrunn" (ref. kristendoms-, religions- og livssynskunnskap, lareplan for 1.-10. årstrinn, lcereplanveiledning og informasjon 2005). Målet om å styrke den enkeltes egen tro er altså dempet, men fortsatt gjenkjennelig. I formål for faget i 2008-planen er dette ytterligere dempet: faget skal nå «gi rom for undring og refleksjon» («Læreplan i religion, livssyn og etikk» 2008). Denne formuleringen kan like gjerne knyttes til det andre ytterpunktet på aksen «styrke tro utfordre tro», for det ville være underlig om elevenes egen tro og tradisjon skulle unntas fra deres undring og refleksjon.

Historisk ser vi altså følgende tendenser i de juridiske dokumentene: Det verdimessige grunnlaget for opplæringen får en bredere forankring i den nyeste formålsparagrafen (enn i den foregående), og hvilke menneskelige instanser opplæringen angår, utvides til å omfatte følelser og holdninger i tillegg til tenkning. Mens det eldste av læreplandokumentene som gjelder alle fag (Generell del), peker ut tilegnelse av et bredt kunnskapsfelt i tillegg til bestemte holdninger som mål for elevenes dannelsesprosess, fokuserer det nyeste allmenne læreplandokumentet (Prinsipp for opplæringa) på dannelsesprosessen. I de innledende delene av fagplanen finner vi en historisk endring fra et mål om å styrke den enkeltes tro til å utfordre den enkeltes tro.

\section{RELIGIONSPEDAGOGIKK OG} RELIGIONS- OG LIVSSYNSDIDAKTIKK

Før jeg går inn på Afdal og Andreassens artikler og deres dannelsesbegrep, vil jeg gjøre rede for begrepsparet «religionspedagogikk» og «religions- og livssynsdidaktikk». I tilknytning til skolens religions- og livssynsundervisning åpner dette begrepsparet for en rekke ulike tolkninger. «Religionspedagogikk» benyttes både $\mathrm{i}$ tilknytning til opplæring innenfor religiøse tradisjoner - altså en teologisk fundert religionspedagogikk - samtidig som begrepet benyttes om en pedagogisk fundert pedagogikk med fokus på religion. Magne Bø viser i sin avhandling hvordan sekulariseringen av skolens religions(og livssyns-) undervisning kan sees som en kontinuerlig utviklingsprosess fra 1739 til 1997, men det er ikke før på 1980-tallet at Winsnes her i Norge argumenterer for en pedagogisk forankret religionspedagogikk ( $\mathrm{B} ø$ 2006; Winsnes 1984, 1988).

Begrepet «religions- og livssynsdidaktikk» ble aktualisert gjennom innføringen av KRL som et felles ikke-konfesjonelt fag for alle elever i norsk grunnskole i 1997. I tilknytning til «religions- og livssynsdidaktikk» er derfor et teologisk fundament utelukket: her dreier det 
seg om en pedagogisk basert undervisning som tematiserer ulike religioner og livssyn. Spenninger knyttet til begrepsparet «religionspedagogikk» og «religions- og livssynsdidaktikk» finnes altså mellom en konfesjonell, teologisk basert opplæring i og til religion og en ikke-konfesjonell, pedagogisk basert opplæring om ulike religioner og livssyn. Før 1997 hadde lærerutdanningen innføringer i religionspedagogikk, etter 1997 har studentene (typisk) fått innføring i «religionsdidaktikk» eller «religions- og livssynsdidaktikk».

Begge begrepene har - ettersom de på konfesjonelt grunnlag kan forstås som ulike disipliner - både praksis- og teorifelt: Konfirmasjonsopplæring vil ofte være eksempel på en teologisk basert religionspedagogikk, med sin tilhørende teori, mens RLE-undervisning i grunnskolen kan være eksempel på religions- og livssynsdidaktisk praksis, og innføringsbøkene for lærerstudenter fra og med 1997 er eksempler på religions- og livssynsdidaktisk teori.

Samtidig blir begrepsparet også benyttet for å vise til henholdsvis teori og praksis: I innledningen til sin avhandling om «forholdet mellom teori og praksis i lærerutdanningsfaget og grunnskolefaget RLE» skriver Dag Husebø:

RLE-undervisningen og den didaktiske samhandling som analyseres betegner jeg som religionsdidaktikk. (...) Det jeg betegner som religionspedagogikk $i$ avhandlingen adresserer et teorinivå. (Husebø 2013)

Jeg har nå pekt på tre ulike måter å forstå begrepsparet på, som også gir tre ulike arenaer der spenninger og nyanser når det gjelder dannelsesbegrepet i nyere religionspedagogikk/ religions- og livssynsdidaktikk kan synliggjøres: Konfesjonell og pedagogisk forankring, tid og forholdet mellom teori og praksis.

De to artiklene jeg har valgt, mener jeg kan illustrere spennet mellom den pedagogisk forankrede religionspedagogikken og religionsog livssynsdidaktikken. Dette spennet kan også - i alle fall i noen grad - knyttes til de ulike vitenskapsfagene der de som jobber i lærerutdanning knyttet til RLE (tidligere KRL) har sin utdanningsbakgrunn. Fram til 1997 var nemlig de aller fleste som var knyttet til religionslærerutdanningen - som da i hovedsak var kristendomslærerutdanning teologisk skolert. Religionsvitere hadde i svært beskjeden grad engasjert seg i lærerutdanning. Og religionspedagogisk/religions- og livssynsdidaktisk teori skrives primært av lærerutdannere knyttet til religions- og livssynsfaget. På dette punktet er et sideblikk til England interessant:

England fikk sin første læreplan for et integrerende religionsfag i 1988 (Bråten 2013; Bø 2006; Grimmitt 1987, 2000; Jackson 1997). $\mathrm{Da}$ hadde religionsvitere aktivt jobbet for endring fra kristendomsfag til ikke-konfesjonelt religionsfag siden 1960-tallet - altså i vel 20 år før det ble etablert. Med faglig bredere engasjement over lengre tid, er det ikke overraskende at mangfoldet av religionspedagogiske tilnærminger innenfor engelsk religionspedagogikk er større enn i Norge. Ikke minst siden 1997 har norske religionspedagoger og religions- og livssynsdidaktikere latt seg inspirere av ulike engelske tilnærminger.

Et spørsmål som tematiseres av den engelske religionspedagogen Michael Grimmitt før 1988 - og som det ikke er enighet om - er i hvor stor grad undervisningen kan og bør involvere elevene i fagstoffet. Spørsmålet omtales ofte med fokus på preposisjoner: Kan og bør elever bare lære om religioner, eller også fra eller av. Å lære fra (eller av) religioner handler om at elevene kan lære om seg selv - sine egne verdier og holdninger gjennom å knytte det religionsfaglige lærestoffet til egne erfaringer og vurderinger. 
ANALYSE AV DANNELSESBEGREPENE I DE TO ARTIKLENE

De to artiklene jeg har valgt å undersøke: «Fragmentert dannelse eller dannelse av fragmenter? Om dannelse, religion, «vår tid» og vårt sted $\gg$ av Geir Afdal (Afdal 2001) og «Religionskritikk som dannelse» av BengtOve Andreassen (Andreassen 2010), er valgt fordi jeg mener de kan illustrere spenningen mellom religionspedagogikk og religions- og livssynsdidaktikk - forstått som henholdsvis teologisk skolert, men pedagogisk fundert religionspedagogikk og religionsvitenskapelig skolert, pedagogisk fundert religions- og livssynsdidaktikk.

\section{Analyse av «Fragmentert dannelse eller dannelse av fragmenter? \\ Om dannelse, religion, «vår tid» og vårt sted $\gg$}

For å synliggjøre det dannelsesbegrepet jeg finner hos Afdal, skal jeg benytte aksene jeg etablerte tidligere, men her lagt inn i en tabell med flere kolonner der aksens ytterpunkter er angitt av stikkord i de to ytterste kolonnene (se figur 2 for illustrasjon: Afdals posisjon i artikkelen er markert med grått). Mellom kolonnene med stikkord er det tre kolonner, slik at det er mulig å angi vekting av det ene eller andre ytterpunkt på aksen, eller at en balanse mellom ytterpunktene er tilstrebet. Alternativt kan interesse for aksens tema markeres i midtkolonnen, uten spesifisering som indikerer ytterpunkt. Dette gir selvsagt et grovt forenklet bilde, men forhåpentligvis kan det nettopp derfor egne seg til å vise spenninger.

Afdals artikkel er publisert i Religion og livssyn, religionslærerforeningens tidsskrift henvendt til lærere i religions- og livssynsfaget i videregående skole og (særlig ungdomstrinnet i) grunnskolen. Den er publisert så tidlig som i 2001, i KRL-fagets fjerde år, og før fagplanen var revidert første gang. Artikkelen er utgitt i en kulturkontekst som også kommer til uttrykk i formuleringer i Generell del, om faren for at «det hele lett bare [blir] flimmer», uten referanserammer som kan gi «flommen av inntrykk og delkunnskaper mening» (Det allmenndannede menneske).

Når det gjelder spørsmålet om hvem som kan bli dannet, får det bred plass hos Afdal. Bakgrunnen for dette er «flimmersamfunnet» - det Afdal kaller postmoderne fragmentering - både på samfunns- og individplan: Elevene som skal dannes, har ikke en enhetlig identitet, men en fragmentert identitet. $\mathrm{Og}$ når det blir umulig «å skape et helhetlig selvstendig individ» (Afdal 2001: 8), «brister også dannelsesprosjektet slik vi har kjent det» (Afdal 2001: 8). Basert på Geir Skeies avhandling En kulturbevisst religionspedagogikk (Skeie 1998) og Marianne Gullestads analyse av en postmoderne ungdoms selvbiografiske tekst (Gullestad 1996 i Afdal 2001), finner Afdal støtte for at også fragmenterte identiteter gir rom for dannelse. $\mathrm{Og}$ det som dannes, er «et fragmentert menneske holdt sammen i en narrativ identitet knyttet til nære andre i tradisjonsbestemte kontekster» (Afdal 2001: 12). Mens han innledningsvis problematiserer muligheten for at noen - med fragmentert, postmoderne identitet - kan dannes i det postmoderne samfunn, konkluderer han altså med at alle kan det.

I avveiningen av betydningen av ytre påvirkning og «frigjøring av menneskets indre» finner Afdal

Argumentene fra et kunnskapsperspektiv [...] slående: Kunnskapen om islams tilblivelse er ikke å finne i menneskets indre, men i larebøker. Altså: Danning krever mote med kunnskap, og denne kunnskap er en del av kulturen som noe transindividuelt. (Afdal 2001: 7)

Afdal tematiserer også spørsmålet om dannelse er noe alle nødvendigvis vil oppnå, eller om det 
er noe den enkelte må anstrenge seg for å oppnå, om dannelse primært er å forstå som prosess eller resultat. Jeg oppfatter ikke at han tar eksplisitt stilling, men tolker ham i retning av at han legger vekt på resultatet, ikke bare prosessen:

Mot [oppfatning av dannelse som prosess] vil andre hevde at det gir mening å snakke om et dannet menneske, både som ideal og virkelighet. Dannelsen må ha et formål, et bilde av et dannet menneske, en mer eller mindre tydelig arbeidsskisse. Først da gis dannelsen en normativ retning, en målestokk for eget og andres liv.

(Afdal 2001: 7)

Avslutningsvis peker likevel Afdal, basert på MacIntyre, bl.a. på at «Dannelse er erkjennelsen av at å søke det gode liv er det gode liv», og gir dermed også tilslutning til et mer prosessorientert dannelsesbegrep.

Afdal er lite opptatt av kunnskap i denne artikkelen. Sitatet om betydningen av ytre påvirkning, og at kildene til dannelse finnes utenfor individet, synliggjør likevel at han anser kunnskap som betydningsfullt, selv om han i liten grad går inn på dette aspektet i artikkelen.

Når det gjelder spørsmålet om religionsundervisningen bør styrke eller utfordre den enkeltes tro, er Afdal oppmerksom på at ikke alle elever har noen tro i tradisjonell forstand. I og med at den religionspedagogiske tradisjonens oppmerksomhet om pluralitet nettopp tar utgangspunkt i sekularisering, er religionspedagoger typisk oppmerksomme på dette: Det er det som er selve grunnlaget for den pedagogisk funderte religionspedagogikken (Asheim 1976). Afdal - med støtte hos bl.a. Skeie - konsentrerer seg derfor snarere om å styrke den enkeltes selvstendighet og tro på seg selv, gjennom avklaring og styrking av den enkeltes identitet. Denne identiteten kan omfatte tilhørighet til en religiøs gruppe, men må ikke det.
Samtidig innebærer Afdals forståelse av «vår tid» og den kulturen elever vokser opp i, at deres tro på og forståelse av seg selv kontinuerlig blir utfordret. I denne situasjonen ønsker Afdal å fremme lokal tilhørighet og identitet, og fremhever samisk læreplan (1997) som et godt eksempel på forsøk på å ivareta samisk identitet som en lokal/regional identitet. Han er også på generelt grunnlag - men igjen med Nord-Norge som eksempel - opptatt av praksiser, og det å ivareta praksiser på grunn av deres interne goder. Han argumenterer altså for å styrke lokale praksiser - bevare en bestående samfunnsorden - gjennom å bevisstgjøre deltagerne om praksisenes interne goder. Målet er å styrke den enkeltes identitet, som deltager i lokale fellesskap, selv om han er klar over at de lokale praksisene ikke nødvendigvis har støtte i storsamfunnets (eksemplifisert som Oslos) herskende verdier. Bevaringsviljen knyttet til lokale praksiser innebærer dermed samtidig en vilje til å fremme andre verdier enn de som er dominerende i samfunnet, gjennom innlevelse i lokale, men likevel, for den enkelte, potensielt fremmede kulturer.

Basert på MacIntyre formulerer Afdal denne viljen til å endre samfunnet - som kjennetegner de fleste moderne forståelser av dannelse - slik:

Dannelse er et moralsk prosjekt $i$ vid forstand. Dannelse er ikke bare å gjøre det rette, men å orientere livet mot virkeliggjørelsen av det gode. Dermed blir grensene mellom dannelse, moral og religion ( $i$ vid forstand) flytende.

(Afdal 2001: 14).

Selv om han skriver om «religion i vid forstand», tror jeg formuleringen om at grensene mellom dannelse og religion er flytende, er egnet til å gjøre lesere uten teologisk forankring skeptiske til hvorvidt grunnlaget for Afdals religionspedagogikk virkelig er pedagogisk, eller om dette er et tegn på at den pedagogiske 
forankringen bare er et ferniss over det som i virkeligheten likevel er en teologisk forankring. Nå skal det sies til Afdals forsvar at han her primært oppsummerer MacIntyre, men han har introdusert MacIntyre fordi han der mener å finne «en dannelsesforståelse som fremmer kulturelt mangfold, men samtidig forsøker å hjelpe individer til sammenheng og retning i sin selvforståelse» (Afdal 2001: 13). Dette er også Afdals mål.

\begin{tabular}{|l|l|l|l|l|}
\hline Alle & & & & Utvalgte \\
\hline Ytre påvirkning & & & & Indre utvikling \\
\hline Oppnåelig & & & & Unnngaelig \\
\hline Nyttig kunnskap & & $?$ & & Klassisk kunnskap \\
\hline Styrke tro & & & & Utfordre tro \\
\hline Resultat & & & & Prosess \\
\hline Lydighet & & & & Selvstendighet \\
\hline Bevare & & & & Mot og endringsvilje \\
\hline Fremme herskende verdi & & & & Innlevelse \\
\hline
\end{tabular}

Figur 2: Afdals dannelsesbegrep markert i grått

\section{Analyse av «Religionskritikk som dannelse»}

Mens Afdal benytter «religionspedagogikk», skriver Andreassen (Andreassen 2010) verken om «religionspedagogikk» eller «religions- og livssynsdidaktikk», men om «religionsdidaktikk». Dette kan sees som uttrykk for ulik vitenskapsfaglig bakgrunn, ønsker om å identifisere seg med ulike fagtradisjoner, men kan også forklares av at Andreassens artikkel er utgitt etter siste revisjon av fagplanen, 13 år etter innføringen av KRL.

Andreassen tar ikke eksplisitt stilling til hvem dannelse kan være oppnåelig for, men gitt konteksten artikkelen står i - en bok om Dannelse i skole og lererutdanning (Brekke 2010), kan vi gå ut fra at han betrakter dannelse som oppnåelig for alle, gjennom ytre påvirkning (skole).

I motsetning til Afdal gjentar Andreassen flere steder i artikkelen at «kunnskaper er viktige»: Religionskritikken som tittelen viser til, presenteres også som aktuelt kunnskapsstoff i faget. Andreassen presiserer at elevene både bør tilegne seg fagkunnskap og lære å anvende den.
Selv om han ikke spesifiserer om det dreier seg om nyttig kunnskap eller klassisk kunnskap, har jeg valgt å markere hele bredden, for å synliggjøre den vekten Andreassen legger på kunnskap, og fordi jeg tolker formuleringene om både å tilegne seg og å anvende kunnskap som indikasjon på at han ønsker begge deler.

Kunnskap er grunnlaget for å reflektere over eget ståsted, og å leve seg inn i andres perspektiv: «Dannelse i religionsfaget handler i mange henseender om å ha tilstrekkelig fagkunnskap til å kunne se andre perspektiver, omtale og forholde seg til det og potensielt la det munne ut $i$ en refleksjon over eget ståsted.» (Andreassen 2010: 63) Dette tolker jeg som uttrykk for at han mener den enkeltes tro bør utfordres i religionsog livssynsundervisningen, gjennom innlevelse i andres perspektiv.

Samtidig hevder Andreassen et annet sted i artikkelen at:

Elevene bør ikke tvinges til å ta stilling til eget 
religiøst eller livssynsmessig ståsted $i$ undervisningen, men arbeidet med religionskritikk kan bidra med perspektiver for elevene. Et eksplisitt arbeid med elevenes religiøse eller livssynsmessige utvikling, selv om den forsøkes legitimert av begrepet «livstolkning» er et inngrep i elevenes personlige og private sfere som ikke bør vere del av en obligatorisk undervisning i offentlig skole, der det skal gis karakterer. Det vil gi undervisningen preg av terapeutisk virksomhet og således peke langt ut over den kompetanse som larere $i$ norsk skole har, og det som er formulert $i$ lareplanene (Andreassen 2008:224-232). Det bor $i$ stedet overlates til foreldre og trossamfunnene.» (Andreassen 2010: 77)

Jeg tolker dette slik at Andreassen er ambivalent til spørsmålet om elevenes tro bør utfordres. Eller kanskje rettere: jeg forstår ham sånn at han er bekymret for at lærere - på tross av læreplanens føringer, og under dekke av betegnelsen «livstolkning» - skal «utvikle» elevenes livssyn i kristen retning. Til grunn for dette ligger blant annet hans drøfting av spørsmålet om elever kan og bør lære om, av og/eller fra religioner. Her er Andreassen, hvis jeg forstår ham rett, mer skeptisk til at elever - med Grimmitts begrep - skal lære $a v$ eller fra religioner, enn sånn jeg har tolket andre RLE-lærerutdannere med religionsfaglig bakgrunn, som Geir Winje (Winje et al. 2009), Tove Nicolaisen og Halldis Breidlid (Breidlid \& Nicolaisen 2011).
Andreassen knytter kunnskaper til fornuft, og peker (basert på Klafki) på fornuftsbestemt selvbestemmelse som mål for dannelsen. Han understreker at dannelse både må omfatte «solide fagkunnskaper og (...) analytisk-kritiske ferdigheter» (Andreassen 2010:67). Samtidig ønsker han at det skal settes spørsmålstegn ved kunnskap og reflekteres over hvor den kommer fra og hva den er uttrykk for: anvendt kunnskap og metakunnskap vil lede til «tenkning om seg selv, eget ståsted og egen kunnskap. Dannelse ses dermed som en vekselvirkning mellom faglig og personlig utvikling.» (Andreassen 2010: 67) Jeg tolker dette som en interesse også for dannelse som prosess og utvikling av elevenes evner.

Når det gjelder spørsmålet om han ønsker å bevare eller endre samfunnet, er det klart at Andreassens fokus på kritiske og analytiske evner, som grunnlag for selvstendighet, korresponderer med vilje til å endre samfunnet. Samtidig finner jeg at de verdiene han ønsker å fremme og styrke gjennom en slik eventuell forandring, er sekularitet - en sekulær skole - og åpenhet for kritikk. Og selv om det kan stilles spørsmål ved om dagens samfunn faktisk verdsetter kritikk, eller bare pynter seg med det ved festlige anledninger, er sekularitet uansett en anerkjent verdi i dagens norske samfunn - i alle fall når det kommer til skolen. Jeg finner derfor at Andreassens dannelsesbegrep i denne artikkelen også søker å bevare visse verdier som er dominerende i dagens norske samfunn.

\begin{tabular}{|l|l|l|l|l|}
\hline Alle & $?$ & & & Utvalgte \\
\hline Ytre påvirkning & $?$ & & & Indre utvikling \\
\hline Oppnåelig & $\boldsymbol{r}$ & & & Unngåelig \\
\hline Nyttig kunnskap & & & Klassisk kunnskap \\
\hline Styrke tro & & & Utfordre tro \\
\hline Resultat & & & Prosess \\
\hline Lydighet & & & Selvstendighet \\
\hline Bevare & & & Mot og endringsvilje \\
\hline Fremme herskende verdi & & Innlevelse \\
\hline
\end{tabular}

Figur 3: Andreassens dannelsesbegrep markert i sort. 
En sammenstilling av Afdals og Andreassens dannelsesbegrep (se figur 4) viser bl.a. at det er en spenning mellom Afdals fokus på identitet, muligheter og mål for dannelse og Andreassens fokus på kunnskap, og større interesse for prosess.

\begin{tabular}{|l|l|l|l|l|}
\hline Alle & $?$ & & & Utvalgte \\
\hline Ytre påvirkning & $?$ & & & Indre utvikling \\
\hline Oppnåelig & $?$ & & & Unngåelig \\
\hline Nyttig kunnskap & \multicolumn{2}{|c|}{} & & Klassisk kunnskap \\
\hline Styrke tro & & & & Utfordre tro \\
\hline Resultat & & & & Prosess \\
\hline Lydighet & & & Selvstendighet \\
\hline Bevare & & & & Mot og endringsvilje \\
\hline Fremme herskende verdi & & & & Innlevelse \\
\hline
\end{tabular}

Figur 4: Afdals og Andreassens dannelsesbegrep sammenstilt

Utvides kildetilfanget knyttet til henholdsvis religionspedagogikk og religions- og livssynsdidaktikk, nyanseres bildet, bl.a. ved at religionsvitere som Østberg (Østberg 1998) og Nicolaisen (Nicolaisen \& Universitetet i Oslo. Det teologiske fakultet 2013) har interessert seg for identitet bl.a. i tilknytning til fortellinger, men også minoritetsgruppers identitetskonstruksjon, mens bl.a. Haakedal (Haakedal 2010a, 2010b) og Lied (Lied 2004) har interessert seg for elevers kunnskapskonstruksjon.

Spenningene jeg viser i dette bildet, må derfor også sees som uttrykk for en utvikling over tid, der spenningene knyttet til aktørenes vitenskapsfaglige utdanningsbakgrunn får mindre betydning: De to artiklene kan nemlig også sees som svar på de læreplanene for grunnskolens religions- og livssynsfag som var aktuelle da artiklene ble utgitt: Afdals interesse for identitet speiler en interesse for dette i KRL-planen fra 1997, der skolen og KRL-faget tillegges en viktig rolle i å demme opp for «flimmersamfunnet». På samme måte kan Andreassens fokus på kunnskap sies å speile kunnskapsfokuset i RLE-planen fra 08 - ikke minst slik det kommer til uttrykk i kompetansemålene. Jeg vil likevel legge til at Afdals interesse for identitet fortsatt har dekning i formålsparagraf, generell del og formål for faget, slik analysene av disse dokumentene viste (jf. ovenfor).

Sammenstilt peker disse artiklene på utfordringer knyttet til dannelse som RLE-faget skal forsøke å løse, nemlig at elever både skal formulere egne synspunkt og utforske sin egen identitet, og samtidig gjøre seg kjent med og ta stilling til andres synspunkt for å utfordre egen identitet og tilegne seg ny kunnskap. Nedenfor vil jeg reflektere over hvordan arbeid med den grunnleggende ferdigheten å uttrykke seg skriftlig kan være en del av svaret på utfordringene Afdal og Andreassens artikler peker på.

\section{OPPSUMMERING AV}

\section{UTFORDRINGER FOR RELIGIONS-}

$$
\text { OG LIVSSYNSFAGET }
$$

Sentralt for den moderne, plurale identitetsforståelsen Afdals artikkel fremhever, utviklet av Skeie (1998), er dette at den enkelte både kan se seg selv som den samme over tid, og identifisere seg med ulike grupper og personer til ulike tider: 
Nye erfaringer må stadig reflekteres over og tas inn i den enkeltes stadig nytolkede fortelling om seg selv, for at opplevelsen av å være den samme over tid skal kunne bevares. Dette innebærer å si noe om "hvor et menneske kommer fra, hvor det er og hvor det har tenkt seg hen." (Skeie 1998: 135). Her ligger det jeg oppfatter som den ene utfordringen både de juridiske dokumentene og artiklene peker på, nemlig å få elevene til å reflektere over hvor de kommer fra, hvor de er og hvem de vil være.

Andreassen mener undervisningen i skolen bør ta utgangspunkt i «vitenskapsfaget religionsvitenskap», og dermed også dette vitenskapsfagets metodologiske ateisme:

Det er mulig å tenke at slike premisser [- at elevene inntar en metodologisk ateisme - ] imotekommer opplaringslovens presisering om at religionsundervisningen skal fremme «vitenskapelig tenkemåte» (\$1-1) og vere «objektiv, kritisk og pluralistisk» (\$2-4) (Andreassen 2010:70).

Andreassen mener også at «Dannelse i religionsfaget handler $i$ mange henseender om å ha tilstrekkelig fagkunnskap til å kunne se andre perspektiver, omtale og forholde seg til disse perspektivene og potensielt la det munne ut i en refleksjon over eget ståsted» (Andreassen 2010: 63). Mens utfordringen jeg fant fra religionspedagogisk hold, dreier seg om å formulere seg om egen identitet, i møte med stadig nye erfaringer, handler utfordringen fra religionsdidaktikk om å prøve ut andre perspektiv enn sitt eget, for eksempel en metodologisk ateisme, for å reflektere over både egen og andres tradisjoner og perspektiv.

\section{SKRIVING FOR DANNELSE I RLE}

I avhandlingen min (Jørgensen 2014) undersøkte jeg ungdomstrinnselevers tekster fra RLE med henblikk på om de viser kompetanser med relevans for dannelse - forstått som selvstendig kritisk tenkning, følelsesmessig engasjement og mot. Basert på arbeidet med avhandlingen skal jeg i det følgende reflektere over hvordan skriving kan brukes i religions- og livssynsfaget både i elevenes arbeid med å formulere seg om hvor de kommer fra, hvor de er og hvem de vil være, og i deres arbeid med å prøve ut andre perspektiv enn sitt eget.

Med utgangspunkt i Bakhtin vil all skriving i likhet med muntlige formuleringer - betraktes som ytringer: ytringer om noe, til noen, og med en bestemt form. Denne forståelsen av ytringer ligger til grunn for bl.a. Sigmund Ongstad (Ongstad 1997) og Jon Smidts (Smidt 2002, 2010, 2011; Smidt \& Evensen 1991) utvikling og bruk av begrepene «posisjonering» - som dreier seg om hvordan den som ytrer seg, stiller seg i forhold til det de ytrer seg om og dem ytringen er henvendt til - og «roller» som indikerer at den som ytrer seg, kan prøve ut flere ulike roller gjennom sine ytringer.

Felles for muntlige og skriftlige ytringer er også - igjen ifølge Bakhtin - at deres menings-innhold er avhengig av konteksten de ytres i: Ytringen «reflekterer direkte den utanomverbale røynda (...) [og får] si fulle meining i denne konteksten» (Bakhtin 1998: 25-26). Konteksten noe blir ytret $\mathrm{i}$, har betydning for meningen som skapes gjennom ytringen. Med tanke på religions- og livssynsfaget forstår jeg dette sånn at dersom elever får i oppgave å ytre seg som om de er ortodokse jøder, innebærer undervisningskonteksten og oppgaven om å leve seg inn i en bestemt (om enn utydelig avgrenset) religiøs gruppes synspunkt og forståelser, at meningen som skapes, ikke omfatter at det som ytres, må være uttrykk for de aktuelle elevenes synspunkt. Å utfordre elever til å formulere seg om hva de har til felles med og på hvilke måter de eventuelt skiller seg fra ortodokse jøder, ville på den annen side legge til rette for at elevene utforsket sin egen identitet.

En forståelse av det å skrive - eller altså 
ytre seg - basert på Bakhtin fremstår dermed som velegnet både med tanke på utfordringen fra religionsdidaktikk og utfordringen fra religionspedagogikk. Ved å understreke muligheten for - gjennom ytringer - å prøve ut ulike roller og posisjoner i forhold til innhold og/ eller adressat for ytringene sine, kan det å leve seg inn $\mathrm{i}$ andres perspektiv og det å posisjonere seg selv i forhold til lærestoff gis et tydelig lærings- og kunnskapsfokus: Det å ytre seg i rolle - eller i en ytring posisjonere seg som en annen enn den man er - blir en måte å lære om den aktuelle gruppens (eller personens) synspunkt og oppfatninger på. Å posisjonere seg som seg selv - i møte med et bestemt lærestoff - blir en måte å lære om seg selv på.

Nå har jeg med vilje overtatt den «bakhtinske» formuleringen «ytring». Ytringsbegrepet omfatter hos Bakhtin både muntlige og skriftlige ytringer, men er også ansett som relevant for analyse av tegninger og multimodale ytringer (Lied 2004). I og med at jeg har avgrenset meg til å snakke med utgangspunkt i grunnskolens religions- og livssynsfag, er det - ikke minst med tanke på elever på lavere trinn - interessant om denne bakhtin-inspirerte forståelsen av ytring, både gjennom tekst og bilde, svarer til læreplanens definisjon av hva den grunnleggende ferdigheten skriving skal være i RLE:

\section{Å kunne uttrykke seg skriftlig i RLE innebcerer å kunne uttrykke kunnskaper om og synspunkter på religion og livssyn, etikk og filosofi. Skriving klargjør tanker, erfaringer og meninger og er en hjelp til å tolke, argumentere og kommunisere. Skriving i RLE innebcerer også å møte ulike estetiske skriftuttrykk og gjøre bruk av dem (Utdanningsdirektoratet 2008).}

Selv om det kanskje ikke er så lett å argumentere gjennom å tegne, er det i alle fall mulig å uttrykke kunnskaper om og synspunkter på fagets emner ved å ytre seg i form av tegninger. Å tegne kan også bidra til å klargjøre tanker, erfaringer og meninger. Enhver ytring i form av en tegning vil også være en tolkning og danne grunnlag for kommunikasjon. De religionspedagogiske og religions- og livssynsdidaktiske utfordringene kan også langt på vei ivaretas gjennom tegning: elever kan reflektere over ny kunnskap, tolke den, reflektere over den og posisjonere seg i forhold til den gjennom å tegne. En Bakhtin-inspirert forståelse av å skrive passer altså like godt på muntlige ytringer og tegninger som på skriftlige ytringer. En Bakhtin-inspirert forståelse av å skrive stemmer altså godt både med en skriving som kreves for å svare på utfordringene fra religionspedagogikk og religions- og livssynsdidaktikk og læreplanens krav, men den er samtidig så vid at den ikke forteller oss hva som er den språklige formuleringens særskilte bidrag.

Jeg vil derfor, med Charles Taylor i Human agency and language (Taylor 1985), stille spørsmålet «What are we bringing about in language and essentially through language, i.e. such that it can only be brought about through language?” (Taylor 1985: 256).

I sitt svar på dette spørsmålet peker Taylor på tre aspekt han mener er særlig viktige:

1) at vi formulerer ting i språk

2) at språk etablerer et offentlig rom og

3) at hva som er viktig for oss som mennesker, formuleres språklig

Ved å påpeke på at vi formulerer ting i språk, ønsker han å rette oppmerksomheten mot dette at vi gjennom språk kan «bring to explicit awareness what we formerly had only an implicit sense of. Through formulating some matter, we bring it to fuller and clearer conciousness $\gg$ (Taylor 1985: 256-257). Språklig, verbal formulering av noe gjør det altså mulig å fokusere på forhold vi ellers bare ville hatt en fornemmelse av. Her kan det innvendes at også tegninger kan innebære formulering av tidligere implisitte fornemmelser. 
Når Taylor fremhever det at språk etablerer et offentlig rom, er det i opposisjon til den språkfilosofien og språkteorien som fokuserer på representativitet - at språklige ytringer kan gi en sann representasjon av virkeligheten:

This blindness to the public is of course (in part anyway) another consequence of the epistemological tradition, which privileges a reconstruction of knowledge as a property of the critical individual. It makes us take the monological observer's standpoint not just as a norm, but somehow as the way things really are with the subject. And this is catastrophically wrong. (Taylor 1985: 259)

Hvis jeg forstår ham rett, hevder altså Taylor at det er umulig gjennom en språklig formulering å gi en sann beskrivelse av virkeligheten. Derimot skaper det å formulere noe språklig, et offentlig rom og et fellesskap der det som tematiseres språklig, kan drøftes av deltagerne. Deltagerne vil da, gjennom sine formuleringer, vise hva som er viktig for dem.

Dette tredje punktet - at hva som er viktig for oss som mennesker, formuleres språklig, handler om at når vi språklig kan skille mellom rett og galt, modig og feigt, synliggjør det menneskelige verdier (human concerns) som ofte er vanskelige å tenke seg og formulere seg om uten språklige uttrykk. Taylor viser i denne sammenheng til hvordan hvilke følelser og verdier vi kan ha, til dels er kulturelt betinget. Disse tre aspektene ved språk avdekker også tre poeng knyttet til språk, nemlig at ytringer har en ekspressiv side, at de alltid vil avsløre noe (og samtidig tilsløre noe annet), og at de er virkelighetskonstituerende.

Det at ytringer er ekspressive, innebærer at vi gir uttrykk for vårt eget syn på saken eller samtalepartneren. (Dette poenget kjenner vi også fra Bakhtin.) Ifølge Taylor viser ytringers ekspressivitet også våre verdier. Dette er relevant i forhold til både den religionspedagogiske utfordringen og den religionsdidaktiske.

At språklige formuleringer allid både avslører og tilslører, innebærer at de er egnet som gjenstand for analyse. Gjennom å analysere språklige formuleringer kan elever utforske både hva formuleringene tilslører, og hvordan de verdiene de ivaretar kommer til uttrykk.

At språklige ytringer er virkelighetskonstituerende, innebærer at de ikke bare beskriver virkeligheten, men også skaper den - bevarer, endrer og dermed gjenskaper virkeligheten. Taylor illustrerer dette med eksempler knyttet til selvforståelse: Om man føler seg skyldig på grunn av en praksis, men siden endrer syn på praksisen, vil man ikke lenger føle seg skyldig på grunn av den - man kan anse skyldfølelsen som resultat av sin oppdragelse, men tillegger ikke lenger praksisen status som uttrykk for en beklagelig moralsk sannhet om seg selv - og dermed er virkeligheten endret.

Jeg er usikker på om Taylors analyse av hva vi gjør i og gjennom språk, utelukker tegning og andre visuelle uttrykksformer som mulige måter å formulere seg på for å oppnå det Taylor peker på: artikulasjon, offentlig rom og formulering av verdier, ekspressivitet, av-/tilsløring og virkelighetskonstituering. Men i mange tilfeller vil det være svært utfordrende å formulere seg uten bruk av språk - for eksempel for elever som ble utfordret til å formulere seg om ortodokse jøders oppfatning om hellighet, historieforståelse og menneskesyn - eller å vise paralleller og differenser mellom ortodokse jøders syn på dette og elevenes eget. I alle fall ville det være svært utfordrende å få frem nyanser og presiseringer. For å uttrykke seg presist, entydig og nyansert ikke minst om abstrakte forhold - finner i alle fall jeg det sannsynlig at mange vil mene at språklige formuleringer er å foretrekke fremfor nonverbale uttrykk.

Det som kjennetegner muntlige ytringer (sammenlignet med skriftlige), er at de muntlige 
er flyktige - de eksisterer bare i øyeblikket - om ikke de tas opp - eller er mellomfenomener, som for eksempel en tale, skrevet ned før den fremføres muntlig. Skriftlige ytringer, derimot, kan bevares over tid.

Grunner til å skrive er at det gir elever (eller andre) anledning til å formulere egne og andres synspunkt språklig som utforskning av egen identitet og tilegnelse av ny kunnskap. Å skrive gir også anledning til - kritisk og analytisk - å avsløre hva ens egne språklige formuleringer forteller og tilslører. Når språklige formuleringer er skriftlige, kan de samme formuleringene undersøkes av ulike elever, og/eller av de samme elevene flere ganger: Både det å la flere undersøke samme tekst og å undersøke den samme teksten flere ganger, vil styrke mulighetene for å avdekke mest mulig både om de verdiene som kommer til uttrykk i teksten og hva den tilslører.

Om elevene selv skriver, kan de gjøre sine egne tekster til gjenstand for analyse: De kan identifisere hvilke verdier og verdivurderinger de har gitt uttrykk for i teksten. Dermed kan skriving både bidra til at elevene får formulert seg om hvem de er - hvor de kommer fra og hvor de vil, og senere tjene som grunnlag for - analytisk og kritisk - å reflektere over om de verdiene de gir uttrykk for i tekstene, fortsatt uttrykker deres verdivurderinger, eller om de nå - gjennom en ny språklig formulering - vil skape en annerledes virkelighet. Dersom skriveoppgaver i RLE på denne måten inviterer til utforskning av egen identitet og andres forståelser og oppfatninger, kan det å skrive fremme dannelse.

\section{LITTERATUR}

Aadnanes, P.M. (2000). Et Fag for enhver smak?: en evaluering av KRL-faget. Oslo: Høgskolesenteret.
Afdal, G. (2001). Fragmentert dannelse eller dannelse av fragmenter. Religion og livssyn (3), s. 5-16.

Andersen, Ø. (red.). (1999). Dannelse, humanitas, paideia. Oslo: Sypress forlag.

Andreassen, B.-O. (2010). Religionskritikk som dannelse. I M. Brekke (red.), Dannelse i skole og lærerutdanning (s. 63-81).

Aristoteles. (1999). Etikk (A. Stigen, overs. 3. utg.). Oslo: Gyldendal akademisk forlag.

Asheim, I. (1976). Religionspedagogikk : en innføring. Oslo: Universitetsforlaget.

Bakhtin, M. (1998). Spørsmålet om talegenrane (R. Slaattelid, overs.). Bergen: Ariadne forl.

Bostadutvalget. (2006). Formålsparagrafen gjennom tidene. Retrieved from http:// view.officeapps.live.com/op/view. aspx?src=http\%3A\%2F\%2Fwww.regjeringen. no\%2Fupload\%2FKD\%2FVedlegg\%2FBosta dutvalget $\% 2$ FForm\%C3\%A5lsparagrafens $\% 2$ 520historie2.doc.

Bostadutvalget. (2007). NOU 2007: 6 Formål for framtida Formål for barnehagen og opplæringen. Retrieved from http:// www.regjeringen.no/nb/dep/kd/dok/ nouer $/ 2007 /$ NOU-2007-6.html id=471461

Breidlid, H., \& Nicolaisen, T. (2011). I begynnelsen var fortellingen (2. utg.). Oslo: Universitetsforl.

Brekke, M. (red.). (2010). Dannelse i skole og lærerutdanning: Universitetsforlaget.

Bråten, O.M.H. (2013). Towards a methodology for comparative studies in religious education : a study of England and Norway. Münster: Waxmann.

Bø, M. (2006). Norsk skole og den etterlengtede helhet: en studie $i$ et lareplanverks forsøk på å skape helhet $i$ et differensiert samfunn og religionens tildelte oppgave $i$ dette forehavende. Trondheim: Norges teknisknaturvitenskapelige universitet. 
Doseth, M. (2011). Paideia - selve fundamentet for vår forståelse av dannelse. I K. Steinsholt \& S. Dobson (red.), Dannelse : introduksjon til et ullent pedagogisk landskap (s. 13-37). Trondheim: Tapir akademisk forlag.

Formålsparagrafen i opplæringslova. (2008). Hentet 6. mars 2013 fra http://www.lovdata. no/all/tl-19980717-061-001.html\#1-1

Grimmitt, M. (1987). Religious education and human development : the relationship between studying religions and personal, social and moral education. Great Wakering, Essex: McCrimmons.

Grimmitt, M. (2000). Pedagogies of religious education : case studies in the research and development of good pedagogic practice in $R E$. Great Wakering: McCrimmons.

Haakedal, E. (2010a). Norwegian Religious Education Workbooks after World War II: Exploring teachers' workbook constructions by interpreting traces of textbooks and national curricula. Scandinavian Journal of Educational Research. Article.

Haakedal, E. (2010b). Tidsbilder fra skolens religionsundervisning: 9- og 10-åringers arbeid med bibelfortellingers verdi- og moralformidling. I J. Smidt, I. Folkvord \& A. J. Aasen (red.), Rammer for skriving. Om skriveutvikling i skole og yrkesliv (s. 207-228). Trondheim: Tapir akademisk forlag.

Haraldsø, B. (1989). 1739-1850 Det stille hundreåret - menighetsskolens tid. I B. Haraldsø (red.), Kirke-- skole-- stat (s. 10-43). Stavanger: IKO-Forlaget.

Haslund, I. (2014). Danning i RLE. Å vise dem det store bildet. I K. Fuglseth (red.), RLE $i$ klemme: ein studie av det erfarte RLE-faget: Akademika.

Holter, Å. (1989). 1850-1890 Det store spranget: fra menighetsskole til borgerskole. I B. Haraldsø (red.), Kirke - skole - stat (s. S. 44-72). Oslo: IKO-Forlaget.
Husebø, D. (2013). Fagdidaktisk utprøving av en fortolkende kulturbevisst tilncerming til Religion, livssyn og etikk-undervisning : om forholdet mellom teori og praksis i lcererutdanningsfaget og grunnskolefaget RLE. Doktorgradsavhandling ved UiS nr. 196

Jackson, R. (1997). Religious education : an interpretive approach. London: Hodder \& Stoughton.

Jørgensen, C.S. (2014). Som du spør får du svar? : en empirisk studie av skriving $i$ religions- og livssynsfaget. Trondheim: Norges teknisknaturvitenskapelige universitet, Fakultet for samfunnsvitenskap og teknologiledelse, Program for lærerutdanning.

Kant, I. (1784). Beantwortung der Frage: Was ist Aufklärung? Berlinische Monatsschrift, 4 (12), 481-494.

Kirke- utdannings- og forskningsdepartementet. (1996). Lareplanverket for den 10-årige grunnskolen. [Oslo]: Nasjonalt læremiddelsenter.

Kjelen, H. (2005). Danningsomgrepet i læreplanar for religionsfaget. Religion og livssyn (2), 27-37.

KRL-boka 2005. (2005). Oslo: Utdanningsdirektoratet.

Lied, S. (2004). Elever og livstolkingspluralitet i KRL-faget: mellomtrinnselever i møte med fortellinger fra ulike religioner og livssyn. (nr 11-2004), Høgskolen i Hedmark, Elverum.

Lied, S. (2009). The Norwegian Christianity, Religion and Philosophy subject KRL in Strasbourg. British Journal of Religious Education, 31(3), 263-275. http://dx.doi. org/10.1080/01416200903112474

Læreplan i religion, livssyn og etikk. (2008). Hentet 6.3. 2013 fra http://www.udir.no/ k106/RLE1-01/

Læringssenteret. (2002). KRL-boka : kristendoms-, religions- og livssynskunnskap : lareplan for den 10-årige grunnskolen : lareplanveiled- 
ning : rundskriv om KRL-faget og begrenset fritak : informasjon til foreldre og skjema for delvis fritak. Oslo: Læringssenteret.

Nicolaisen, T., \& Universitetet i Oslo Det teologiske fakultet. (2013). Hindu-barn $i$ grunnskolens religions- og livssyns-undervisning : egengjøring, andregjøring og normalitet. Oslo: Det teologiske fakultet, Universitetet i Oslo.

Ongstad, S. (1997). Sjanger, posisjonering og oppgaveideologier : et teoretisk-empirisk bidrag til et tverrfaglig, semiotisk og didaktisk sjangerbegrep. Trondheim: Norges teknisknaturvitenskapelige universitet.

Prinsipp for opplæringa. (2006).http://www.udir. no/Lareplaner/Kunnskapsloftet/Prinsippfor-opplaringa/: Utdanningsdirektoratet Retrieved from http://www.udir.no/ Lareplaner/Kunnskapsloftet/Prinsipp-foropplaringa/.

Schiller, F. (1991). Om menneskets estetiske oppdragelse i en rekke brev (S. Dahl, overs.). Oslo: Solum.

Skeie, G. (1998). En kulturbevisst religionspedagogikk. Trondheim: Norges teknisknaturvitenskapelige universitet.

Smidt, J. (2002). Double Histories in Multivocal Classrooms. Notes Toward an Ecological Account of Writing. Written Communication, 19(3), 414-443.

Smidt, J. (2010). Skrivekulturer og skrivesituasjoner i bevegelse - fra beskrivelser til utvikling. I J. Smidt (red.), Skriving $i$ alle fag innsyn og utspill (s. 11-35). Trondheim: Tapir akademisk forlag.

Smidt, J. (2011). Ti teser om skriving i alle fag. I J. Smidt, R. Solheim \& A. J. Aasen (red.), På sporet av god skriveopplaring - ei bok for larere $i$ alle fag (s. 9-41). Trondheim: Tapir akademisk forlag.
Smidt, J., \& Evensen, L.S. (1991). Roller i relieff: skrivestrategier - tekster - lesestrategier (Vol. nr 6). Trondheim: Senter for samfunnsforskning, Universitetet i Trondheim.

Taylor, C. (1985). Philosophical papers 1. Human agency and language. Cambridge: Cambridge University Press.

Telhaug, A.O. (2011). Dannelsesbegrepet $i$ grunnskolens lareplaner - fra 1939 til 2006. I K. Steinsholt \& S. Dobson (red.), Dannelse : introduksjon til et ullent pedagogisk landskap (s. 211-254). Trondheim: Tapir akademisk forlag.

Utdanningsdirektoratet. (2008). Læreplan i religion, livssyn og etikk. Hentet 07.08.2009, fra http://skolenettet.no/lkt/TM_Laereplan.aspx?id=36376\&laereplanId=94712\&ep slanguage $=\mathrm{NO}$

Winje, G., Eidhamar, L.G., Sødal, H.K., Hodne, H., Skeie, G., \& Danielsen, R. (2009). Religions- og livssynsdidaktikk : en innføring (4. utg.). Kristiansand: Høyskoleforl.

Winsnes, O.G. (1984). Kristendomskunnskap erfaring - kommunikasjon: en samling artikler om religionspedagogiske emner. Trondheim: Tapir akademisk forlag.

Winsnes, O.G. (1988). E' du rel'giøs, eller - ?: om konseptualisering og metodologi i empirisk religionsforskning. [Trondheim]: Det historiskfilosofiske fakultet, Den allmennvitenskapelige høgskolen, Universi-tetet i Trondheim.

Wyller, E.A. (1999). Werner Jaeger og hans 'paideia'. I Ø. Andersen (red.), Dannelse, humanitas, paideia (s. 255-265). Oslo: Sypress forlag.

Østberg, S. (1998). Pakistani children in Oslo : Islamic nurture in a secular context. [Warwick]: [University of Warwick]. 